\title{
Intracellular and extracellular factors influencing the genotoxicity of nitric oxide and reactive oxygen species
}

\author{
MIN YOUNG KIM \\ Toxicology Laboratory, College of Applied Life Sciences, SARI, Jeju National University, Jeju 690-756, Republic of Korea
}

Received January 26, 2016; Accepted October 28, 2016

DOI: $10.3892 / 01.2017 .5584$

\begin{abstract}
A number of factors affect cellular responses to nitric oxide $\left(\mathrm{NO}^{\circ}\right)$ and reactive oxygen species (ROS), including their source, concentration, cumulative dose, target gene and biological milieu. This limits the extrapolation of data to in vivo pathological states in which $\mathrm{NO}^{*}$ and ROS may be important. The present study investigated lethality and mutagenesis in the HPRT and TK1 genes of human lymphoblastoid TK6 cells exposed to NO ${ }^{*}$ and ROS derived from two delivery methods: A reactor system and a Transwell $^{\mathrm{TM}}$ co-culture. The delivery of $\mathrm{NO}^{\circ}$ into the medium at controlled steady-state concentrations (given in $\mu \mathrm{M} / \mathrm{min}$ ) and the production of $\mathrm{NO}^{\bullet}$ and ROS by activated macrophages, resulted in a time-dependent decrease in total cell numbers, and an increase in mutation frequency (MF), compared with untreated controls. This increase in MF was effectively suppressed by $N$-methyl-L-arginine monoacetate. Single base substitutions were the most common type of spontaneous and $\mathrm{NO}^{\bullet}$ induced mutations in HPRT, followed by exon exclusions and small deletions in both delivery systems. Among the single base pair substitutions, an equal frequency of four types of single base substitutions were identified in TK6 cells exposed to $\mathrm{NO}^{\circ}$ delivered by the reactor system, whereas $\mathrm{G}: \mathrm{C}$ to $\mathrm{T}: \mathrm{A}$ transversions and $\mathrm{A}: \mathrm{T}$ to $\mathrm{G}: \mathrm{C}$ transitions were more frequent in the co-culture system. Taken together, these results demonstrate that both the delivery method of $\mathrm{NO}^{\circ}$ and ROS, and the target genes are determinants of observed cytotoxic and mutagenic responses, indicating that these parameters need to be considered in assessing the potential effects of NO and ROS in vivo.
\end{abstract}

\section{Introduction}

At low levels, nitric oxide (NO*) is a signaling molecule required for many physiological functions. However, when

Correspondence to: Professor Min Young Kim, Toxicology Laboratory, College of Applied Life Sciences, SARI, Jeju National University, Ara-1 Dong, Jeju 690-756, Republic of Korea

E-mail: jeffmkim@jejunu.ac.kr

Key words: nitric oxide, reactive oxygen species, intracellular and extracellular factors, genotoxicity, TK6 cells produced in excessive amounts, for example, by inflammatory cells, it can cause cell death and mutagenicity, as demonstrated by numerous experiments in cultured cells and experimental animal models $(1,2)$. The concentration, source and cumulative dosage of $\mathrm{NO}^{\circ}$, as well as the composition of biological milieu, can affect cellular responses. $\mathrm{NO}^{\bullet}$ acts on cells and tissues in three ways: By diffusing into cells and undergoing intracellular consumption, autoxidating to form nitrous anhydride $\left(\mathrm{N}_{2} \mathrm{O}_{3}\right)$, and reacting with superoxide $\left(\mathrm{O}_{2}^{-{ }^{-}}\right)$to form peroxynitrite $\left(\mathrm{ONOO}^{-}\right)(1,2)$. The reactive oxygen species (ROS) formed by these reactions may then react further: $\mathrm{ONOO}^{-}$reacts with carbon dioxide to form nitrosoperoxycarbonate $\left(\mathrm{ONOOCOO}^{-}\right) ; \mathrm{N}_{2} \mathrm{O}_{3}, \mathrm{ONOO}^{-}$and $\mathrm{ONOOCOO}^{-}$breakdown to form reactive species such as hydroxyl radicals $\left(\mathrm{OH}^{\circ}\right)$, nitrogen dioxide radicals $\left(\mathrm{NO}_{2}{ }^{\circ}\right)$ and carbonate radical anions $\left(\mathrm{CO}_{3}^{-{ }^{-}}\right)$; and all of these species may react with cellular molecules (1,3-9). Overproduction of these reactive species under pathological conditions such as inflammation induces oxidative and nitrosative stress and damages cellular macromolecules, which increases levels of mutation and carcinogenesis (3-9).

Adverse responses to $\mathrm{NO}^{\bullet}$ reflect qualitative and quantitative variation among different types of cells. Apoptosis is the main mechanism by which cell death occurs at low doses of $\mathrm{NO}^{*}$, whereas necrosis occurs more readily at higher doses. However, there is a wide variation of responses to $\mathrm{NO}^{\bullet}$ among different cell types. For example, sub-millimolar concentrations of $\mathrm{NO}^{-}$-donor drugs rapidly induce cell death in macrophages, however, they have no obvious effect on cultured hepatocytes. Furthermore, some cell types, such as human lymphoblastoid cells, are sensitive to apoptosis, whereas others, including HCT116 human colon cancer cells, exhibit resistance (2). These differences may be down to the actions of other factors acting on the cell. Antioxidants (for example, glutathione and flavonoids) can alter the apoptosis-inducing potency of different $\mathrm{NO}^{\bullet}$ donors. Other cellular factors, such as enzymatic scavengers of free radicals (including superoxide dismutase and catalase) may also contribute to the differences in sensitivity of cell to $\mathrm{NO}^{\circ}$-induced cell death.

Factors affecting the mutagenic potency induced by $\mathrm{NO}^{\circ}$ have not yet been extensively characterized. Previous studies by our group have demonstrated that $\mathrm{NO}^{\circ}$ and the ROS derived from it are strongly mutagenic in the supF shuttle vector pSP189 exposed to large single bolus doses of ONOO', NO` gas or unstable donors (10-13). While providing useful 
mechanistic information, exposure under these conditions limits extrapolation of the data to in vivo pathological states in which these radicals may play a role. To address this issue, studies aimed at developing well-defined experimental models that could be exposed to more pathophysiologically relevant conditions, and defining the mechanisms responsible for $\mathrm{NO}^{\circ}$ and ROS-associated genotoxicity have been performed by our group (14-20). The effects of DNA damage, mutational frequencies and spectra induced by varying bolus doses of $\mathrm{ONOO}^{-}$were compared with those induced by slow infusion of $\mathrm{ONOO}^{-}$and by SIN-1, which slowly decomposes to release $\mathrm{NO}^{-}$and $\mathrm{O}_{2}^{-}$, thus producing $\mathrm{ONOO}^{-}(14,15)$. A co-culture system $(17,18)$ was also employed in which target cells were co-cultivated with mouse macrophages (RAW 264.7) and stimulated to produce $\mathrm{NO}^{*}$ by interferon- $\gamma(\mathrm{IFN}-\gamma)$ and lipopolysaccharide (LPS), to characterize genotoxic responses in endogenous hypoxanthine-guanine phosphoribosyltransferase (HPRT) and thymidine kinase (TK1) genes (17) as well as the transfected supF gene (18). $\mathrm{NO}^{\circ}$-induced mutagenesis of the TK1 gene in TK6 (wild-type p53) and NH32 (p53 null) cells using an $\mathrm{NO}^{\circ}$ reactor specifically designed to provide tightly controlled steady state concentrations of $\mathrm{NO}^{\circ}$ and molecular oxygen $\left(\mathrm{O}_{2}\right)$ have also been examined (16).

The present study sought to mimic the conditions in inflamed tissues to assess how $\mathrm{NO}^{\bullet}$ and the reactive species derived from it increase carcinogenic risk. The modulating influences of additional factors on cytotoxicity and mutagenesis induced by $\mathrm{NO}^{\circ}$ and associated ROS were assessed using two delivery methods (reactor and co-culture systems). For co-culture experiments, a modification of the Costar Transwell ${ }^{\mathrm{TM}}$ system was introduced that places target and generator cells into close proximity $(1 \mu \mathrm{m})$ whilst facilitating their separation following treatment. The target cells used for these experiments were human lymphoblastoid TK6 cells, which have been used extensively in mutagenicity studies $(14,16,21-23)$. The relative contribution of $\mathrm{NO}^{*}$ to mutagenesis was also investigated by employing an $\mathrm{NO}^{\bullet}$ synthase inhibitor.

\section{Materials and methods}

Cell cultures and chemicals. Mouse macrophage-like RAW264.7 cells (American Type Culture Collection, Manassas, VA, USA) were cultured in high glucose Dulbecco's modified Eagle's medium (DMEM) containing L-glutamine supplemented with $100 \mathrm{U} / \mathrm{ml}$ penicillin, $100 \mu \mathrm{g} / \mathrm{ml}$ streptomycin and $10 \%$ heat-inactivated fetal bovine serum (Atlanta Biologicals, Lawrenceville, GA, USA). Cells from the human lymphoblastoid TK6 cell line were provided by Dr Gerald N. Wogan (Massachusetts Institute of Technology, Cambridge, MA, USA), and maintained in RPMI-1640 medium supplemented with antibiotics and 10\% heat-inactivated horse serum (Lonza Group Ltd., Basel, Switzerland). Before each experiment, cell cultures were treated with CHAT $(10 \mu \mathrm{M}$ 2'-deoxycytidine, $20 \mu \mathrm{M}$ hypoxanthine, $0.1 \mu \mathrm{M}$ aminopterin, and $17.5 \mu \mathrm{M}$ thymidine) according to a standard protocol to remove pre-existent mutant cells (21).

Reagents and materials were obtained as follows: Gases from Air Gas (Edison, NJ, USA); Silastic ${ }^{\mathrm{TM}}$ tubing (0.058 in. i.d., 0.077 in. o.d.) from Dow Corning (Auburn, MI, USA); NO• synthase and ${ }^{\circ} \mathrm{OH} / \mathrm{ONOO}^{-}$detection kit from Cell Technology,
Inc. (Fremont, CA, USA); total $\mathrm{NO}^{\circ}$ immunoassay kit and recombinant mouse IFN- $\gamma$ from R\&D Systems, Inc. (Minneapolis, MN, USA); Escherichia coli LPS (serotype 0127:B8), 4,5-dihydroxy-1,3-benzene-disulfonic acid (tiron), uric acid, 4-nitroquinoline 1-oxide (4-), 6-thioguanine (6-TG), and trifluorothymidine (TFT) all from Sigma-Aldrich (St. Louis, MO, USA); and $N$-methyl-L-arginine monoacetate (NMA) from CalBiochem Research (EMD Millipore, Billerica, MA, USA).

Exposure of target cells to $\mathrm{NO}^{\bullet}$ in a reactor system. Cells were exposed to $\mathrm{NO}^{\circ}$ by diffusion through permeable Silastic ${ }^{\mathrm{TM}}$ tubing utilized for specially designed reactors, with which $\mathrm{NO}^{*}$ dose and dose-rate is tightly controlled at steady state concentrations as described previously $(16,24)$. TK6 cells, which grow in suspension, were cultivated with a density of $5 \times 10^{5}$ cells $/ \mathrm{ml}$ in $110 \mathrm{ml}$ of culture medium and exposed to $\mathrm{NO}^{\circ}$ at a steady state concentration of $0.6 \mu \mathrm{M}$. The total $\mathrm{NO}^{\bullet}$ dose delivered into the medium was controlled by varying the exposure time. Cells exposed to argon gas under the same conditions served as negative controls.

Intracellular NO ${ }^{\circ}$ and ROS synthesis in RAW 264.7 cells. Generation of NO` and ROS by RAW 264.7 macrophages was determined using fluorescent probes (Cell Technology, Inc.). Macrophages were plated in a black, clear bottom 96-well microplate $\left(1 \times 10^{5}\right.$ cells/well) and incubated for $6 \mathrm{~h}$ to allow cells to adhere. Cells were then washed twice with HBSS and preloaded with dye before incubation at $37^{\circ} \mathrm{C}$ for $60 \mathrm{~min}$ with either $10 \mu \mathrm{M}$ diaminofluorescein-2 diacetate (DAF-2DA) for $\mathrm{NO}^{\bullet}$ detection, or $10 \mu \mathrm{M}$ hydroxyphenyl fluorescein (HPF) for detection of ROS. After washing twice with HBSS to remove excess dye, cells were incubated for $8 \mathrm{~h}$ in $100 \mu \mathrm{l}$ of fresh medium in the presence or absence of $20 \mathrm{U} / \mathrm{ml}$ IFN $-\gamma$ and $20 \mathrm{ng} / \mathrm{ml}$ LPS. In some experiments, NMA, tiron, uric acid or combinations thereof were also added. After $8 \mathrm{~h}$ incubation, fluorescence intensity was measured in a multi plate Spectra Max Gemini fluorescence reader (Molecular Devices LLC, Sunnyvale, CA, USA) in triplicate and averaged every $100 \mathrm{sec}$ for $1 \mathrm{~h}$ at $37^{\circ} \mathrm{C}$. Excitation and emission wavelengths were set at 488 and $515 \mathrm{~nm}$, and medium blanks corrected for auto fluorescence.

Co-culture of TK6 with RAW264.7 cells in a modified Transwell $^{T M}$ system. Transwell ${ }^{\mathrm{TM}}$ permeable supports (Corning Inc., NY, USA) consist of $100 \mathrm{~mm}$ culture dishes each containing a $75 \mathrm{~mm}$ diameter insert carrying a polycarbonate membrane with $0.4 \mu \mathrm{m}$ pores that separates two chambers. This design allows the free exchange of fluids but no direct contact between generator and target cells, even when both are adherent. Co-culture of TK6 cells with macrophages was performed by the following modified procedure: i) The membrane-supporting insert was inverted and macrophages $\left(1 \times 10^{7}\right.$ cells) were seeded onto the bottom surface of the membrane after pretreatment with medium for $1 \mathrm{~h}$ at $37^{\circ} \mathrm{C}$, ii) After $6 \mathrm{~h}$ incubation to allow macrophage attachment, the insert was restored and the two-chamber unit was assembled in the usual configuration, iii) $12 \mathrm{ml}$ of culture medium, containing 20 units/ml IFN- $\gamma$ and $20 \mathrm{ng} / \mathrm{ml} \mathrm{LPS}$, with or without various combinations of $2 \mathrm{mM}$ NMA, $1.25 \mathrm{mM}$ tiron, 
and $1.25 \mathrm{mM}$ uric acid, was inserted into the lower chamber of the Transwell ${ }^{\mathrm{TM}}$ device, iv) TK6 cells suspended in $9 \mathrm{ml}$ medium were placed into the upper compartment, v) The concentration of NMA and a nonspecific NOS inhibitor, which were effective in reducing cytotoxicity (MTT assay, data not shown) was established using modifications of conditions outlined in Li et al (14).

Two preliminary experiments were performed to establish optimal co-culture conditions suitable for assessment of mutagenic responses. First, it was confirmed that TK6 target doses do not produce detectable amounts of $\mathrm{NO}^{*}$ when cultured with IFN- $\gamma /$ LPS for $24 \mathrm{~h}$. Following this, the TK6 cell to macrophage ratio was established based on $\mathrm{NO}^{\circ}$-induced cytotoxicity. In order to evaluate mutagenic responses at equivalent levels of cell survival, TK6 cells were co-cultured with macrophages at a ratio of $1: 2\left(5 \times 10^{6}: 1 \times 10^{7}\right)$ in DMEM for $24 \mathrm{~h}$ with shaking to prevent settling of suspended cells. Following co-culture, TK6 cells were collected, washed twice and re-suspended in $10 \mathrm{ml}$ of culture medium prior to analysis.

Following each period of co-culture, $\mathrm{NO}_{2}{ }^{-}$as well as total $\mathrm{NO}^{-}\left(\mathrm{NO}_{3}^{-}\right.$plus $\left.\mathrm{NO}_{2}^{-}\right)$content of cell supernatants were measured using an immunoassay kit (R\&D Systems, Inc.). $\mathrm{NO}_{2}^{-}$was measured by allowing $50 \mu \mathrm{l}$ of culture supernatant to react with $100 \mu \mathrm{l}$ of Griess reagent at room temperature for 10-30 min. To measure total $\mathrm{NO}^{\bullet}$ production, $\mathrm{NADH}$ and $\mathrm{NO}_{3}{ }^{-}$reductase were added before reaction with the Griess reagent, and absorbance was measured at $540 \mathrm{~nm}$ using a micro plate reader. Total $\mathrm{NO}^{-}$and $\mathrm{NO}_{2}{ }^{-}$concentrations were calculated from standard curves derived from standard solutions provided, with fresh culture media serving as the control.

Cell viability. Cell viability $24 \mathrm{~h}$ after treatment was determined by trypan blue exclusion, which had previously produced results comparable to those determined by plating efficiency and MTT assay $(18,21)$.

HPRT mutation assay. Following treatment, TK6 cells were maintained for 7 days to allow phenotypic expression. A total of $24 \times 10^{6}$ cells were placed into ten 96 -well micro titer plates at densities of $4 \times 10^{4}$ cells/well in medium containing $2 \mu \mathrm{g} / \mathrm{ml}$ of 6-TG and TFT to select HPRT and TK1 mutants, respectively. For plating efficiency, cells from each culture were plated into 96-well dishes at 1 cell/100 $\mu \mathrm{l} /$ well in the absence of selective agents. After 2 weeks of incubation, colonies were counted and mutation fractions (MFs) were calculated as described by Li et al (16). A single HPRT mutant colony was then transferred to 24 well plates to propagate mutant cells. Approximately $2 \times 10^{6}$ mutant cells were collected for molecular analysis. The spontaneous MF was estimated from the argon-treated cells for $\mathrm{NO}^{*}$ treatment or untreated cells for co-culture. Cells treated with 4-NQO (140 ng/ml for $1.5 \mathrm{~h})$ served as positive controls.

Total RNA isolation, RT-PCR for determining point mutations and intragenic deletions in HPRT mutants and sequencing. Total RNA from each mutant clone was isolated using TRI-reagent (Sigma Aldrich) according to the manufacturer's protocol, and stored at $-80^{\circ} \mathrm{C}$. $2 \mu \mathrm{g}$ RNA was used as a template for the reverse transcription polymerase chain reaction (RT-PCR) with Omniscript Reverse Transcription kits (Qiagen GimbH, Hilden, Germany) and the oligo(dT)15 primer (Promega Corporation, Madison, WI, USA) provided for first-strand cDNA synthesis. The reaction was performed at $37^{\circ} \mathrm{C}$ for $1 \mathrm{~h}$ to allow the lysis of cell membrane and the synthesis of first-strand cDNA from polyadenylated mRNA. Amplification of the cDNA was performed in two rounds of nested PCR in a PTC-200 DNA Engine Thermal Cycler (Bio-Rad Laboratories, Inc., Hercules, CA, USA). A $10 \mu 1$ aliquot of cDNA solution was transferred into the first round mix of $10 \mu 1$ 10x PCR buffer, $2 \mu 1 \mathrm{dNTP}$ mix, $0.5 \mu 1$ taq polymerase, $73.5 \mu 1$ high powered liquid chromatography-grade water, $0.2 \mu 1$ each $25 \mathrm{mM}$ forward (bases -60 to -41 ; 5'-CTGCTCCGCCACCGGCTTCC-3') and reverse (bases -721 to -702; 5'-GATAATTTTACTGGCGATGT-3') primer and amplified with a PCR profile of $94^{\circ} \mathrm{C}: 1 \mathrm{~min}, 30$ cycles of $94^{\circ} \mathrm{C} ; 1 \mathrm{~min}, 61^{\circ} \mathrm{C} ; 1 \mathrm{~min}, 72^{\circ} \mathrm{C} ; 1 \mathrm{~min}$ and a final extension of $72^{\circ} \mathrm{C}$ for $7 \mathrm{~min}$. The product from this reaction was filtered using a Centricon 50 concentrator (Amicon; EMD Millipore) and resuspended in $100 \mu 1$ sterile water to avoid unspecific binding with remaining primers. $10 \mu \mathrm{l}$ aliquot was used as template in the second round of PCR using nested primers (bases -36 to -17; 5'-CCTGAGCAGTCAGCCCGCGC-3' and bases 701-682; 5'-CAATAGGACTCCAGATGTTT-3'). The PCR conditions were the same in the second round reaction as those in the first round. The final product was run on a $1 \%$ agarose gel, stained with etidium bromide and observed under ultraviolet light. For direct sequencing of HPRT PCR products, the nested PCR products were purified by a QIAquick PCR Purification Kit (Qiagen GimbH) and aliquots of these PCR products were then sequenced by the Dana-Farber/Harvard Cancer Center DNA Resource Core (Boston, MA, USA) using three primers with the following sequences: Bases 264-252; 5'-ATTTCTATTCAGT-3', bases 169-181; 5'-ATGGGAGGC CATC-3' and bases 405-417; 5'-TATAATTGACACT-3' (Integrated DNA Technologies, Coralville, IA, USA), using an adapted method (25).

Statistical analysis. All experiments were repeated 2-4 times. The two-tailed Student's t-test was used for the comparison of test and control group, and $\mathrm{P}<0.05$ was considered to indicate a statistically significant difference.

\section{Results}

Cytotoxicity and mutagenicity of $\mathrm{NO}^{*}$ in target cells by reactor system. TK6 cells were exposed for 2-24 h to $\mathrm{NO}^{\bullet}$ at a steady state concentration of $0.6 \mu \mathrm{M}$, resulting in cumulative total $\mathrm{NO}^{\bullet}$ doses ranging from $90-918 \mu \mathrm{M} / \mathrm{min}$, which induced cell death in a dose-dependent manner (Fig. 1A). The cell viability of TK6 cells was $36 \% 24 \mathrm{~h}$ after a dose of $540 \mu \mathrm{M} / \mathrm{min} \mathrm{NO}^{\circ}$ (Fig. 1A). The mutagenicity of $\mathrm{NO}^{\circ}$ in the HPRT and TK1 genes of TK6 cells was also investigated (Fig. 1B). At a total dose of $540 \mathrm{e} / \mathrm{min}$ of $\mathrm{NO}^{\circ}$, induced MFs in the HPRT and TK1 genes were $7.7 \times 10^{-6}(\mathrm{P}<0.05)$ and $24.8 \times 10^{-6}(\mathrm{P}<0.01), 2.7$ - and 3.7-fold higher than background $\left(2.9 \times 10^{-6}\right.$ and $\left.6.7 \times 10^{-6}\right)$, respectively (Fig. 1B). MFs at the HPRT and TK1 loci in 4-NQO-treated positive controls were $14.6 \times 10^{-6}$ and $28.1 \times 10^{-6}$, respectively.

Intracellular production of $\mathrm{NO}^{\bullet}$ and ROS in activated macrophages. To quantify intracellular $\mathrm{NO}^{\bullet}$ and ROS 

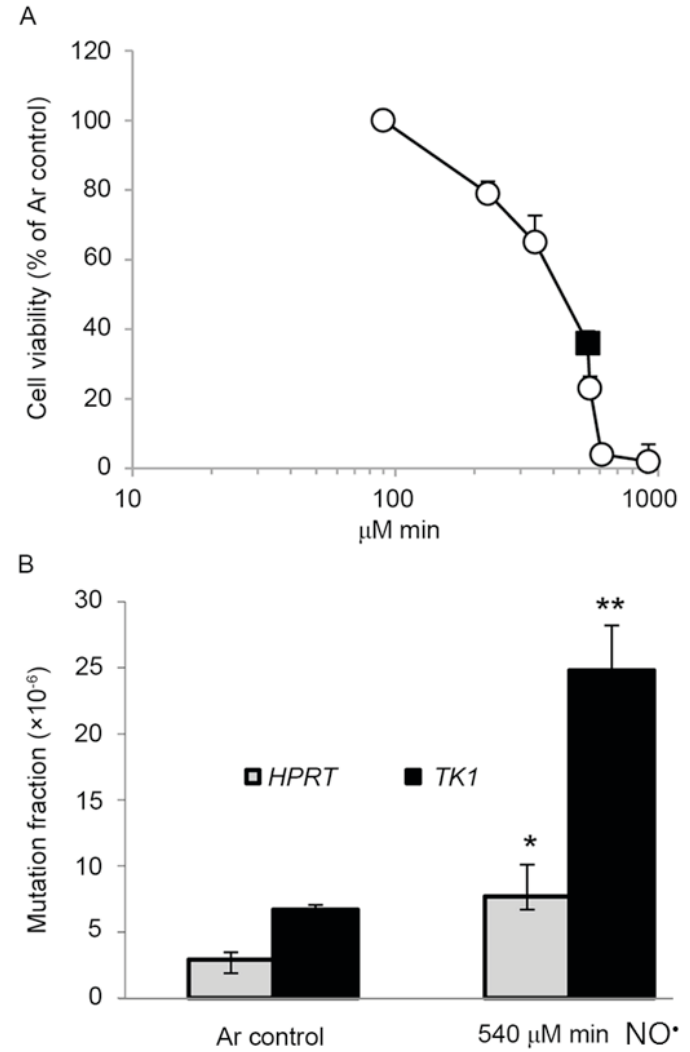

Figure 1. Cell survival and mutagenesis following exposure of TK6 cells to nitric oxide (NO) by a reactor system. (A) Survival was determined by a trypan blue assay $24 \mathrm{~h}$ after NO${ }^{*}$ treatment. (B) Mutation fraction in the thymidine kinase (TK1) and hypoxanthine-guanine phosphoribosyltransferase (HPRT) genes of TK6 cells exposed to $540 \mu \mathrm{M} \bullet \min \mathrm{NO}^{\bullet}$. Cells treated with Argon acted as negative controls. Data represent mean \pm standard deviation for three measurements. ${ }^{*} \mathrm{P}<0.05$ and ${ }^{* *} \mathrm{P}<0.01$ vs. the untreated control.

production by macrophages, DAF-2T and HPF fluorescence intensities were measured for $1 \mathrm{~h}$, beginning $8 \mathrm{~h}$ after activation with IFN- $\gamma /$ LPS (Fig. 2). NO converts the non-fluorescent dye, DAF-2, to its fluorescent triazole derivative, DAF-2T (26). The fluorescence of DAF-2T increased continuously (Fig. 2A), confirming increased $\mathrm{NO}^{\bullet}$ production by macrophages stimulated with IFN $-\gamma /$ LPS. The probe HPF was used as an index of the production of ROS, primarily $\mathrm{ONOO}^{-}$and ${ }^{\circ} \mathrm{OH}$, which exhibited a modest increase up to $\sim 30 \mathrm{~min}$, after which production tended to plateau (Fig. 2B). These experiments indicate that $\mathrm{NO}^{\circ}$ and ROS were intracellularly generated by activated macrophages (Fig. 2).

Various treatment regimens were used to provide additional evidence regarding the reactive species responsible for these effects, by introducing an inhibitor and scavengers, including NMA (a $\mathrm{NO}^{\circ}$ synthase inhibitor), tiron (an $\mathrm{O}_{2}{ }^{-}$ scavenger) and uric acid $\left(\mathrm{O}_{2}{ }^{-}\right.$and $\mathrm{ONOO}^{-}$scavengers $)$, alone or in combination (NMA+ tiron or NMA+ tiron +uric acid). Intracellular fluorescence of DAF-2T, i.e., NO-derived fluorescence, was almost completely suppressed by NMA, and was partially suppressed by uric acid (Fig. 2A). By contrast, HPF fluorescence intensity, the ROS probe, was effectively blocked by uric acid but was not significantly affected by NMA (Fig. 2B). Results obtained in the presence of the both probes demonstrated that tiron and/or uric
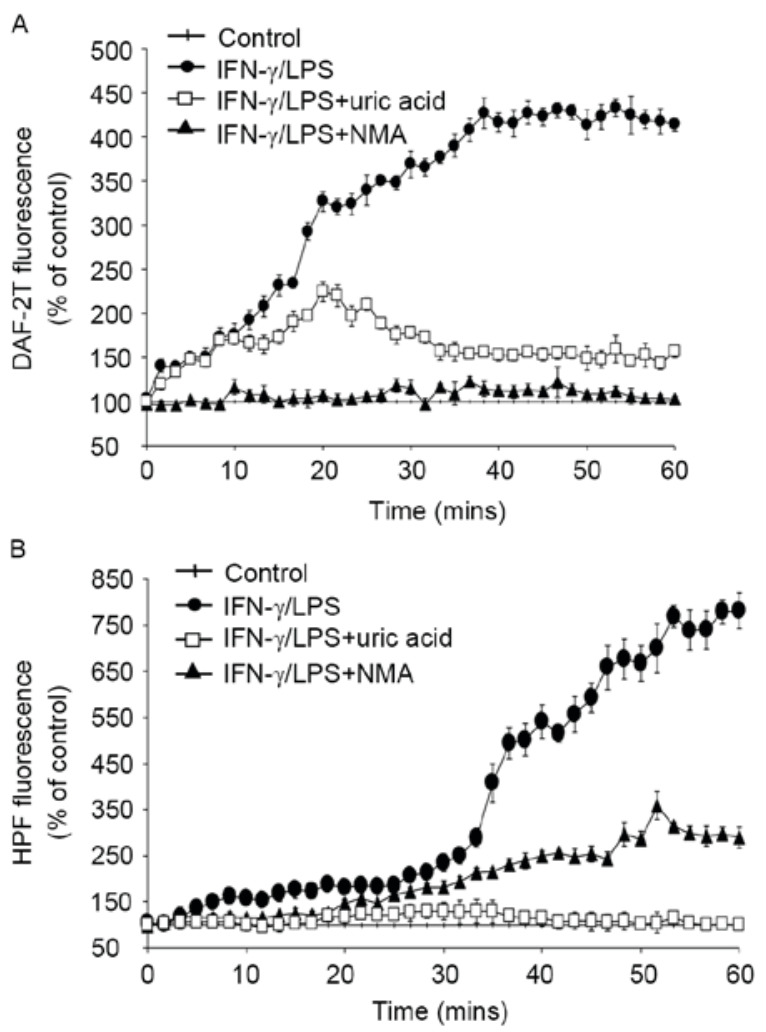

Figure 2. Increase in fluorescence intensity according to nitric oxide (NO*) and reactive oxygen species (ROS) production from RAW 264.7 cells DAF-2T (A) and HPF (B) fluorescence intensity induced by macrophages stimulated with interferon- $\gamma /$ lipopolysaccharide (IFN- $\gamma /$ LPS) in the absence or presence of $N$-methyl-L-arginine monoacetate (NMA) and uric acid. Fluorescence is expressed as the \% of control values obtained in the absence of IFN- $\gamma /$ LPS. Data represent mean \pm standard deviation for three measurements.

acid in combination with NMA reduced total fluorescence almost completely (data not shown), confirming that $\mathrm{NO}^{*}$ and ROS were of central importance as a reactive species produced by activated macrophages. Additionally, MTT assays performed at the beginning and end of each experiment confirmed that the observed changes in fluorescence intensity were not attributable to changes in cell survival (data not shown).

Viability, NO production and mutagenesis in TK6 cells co-cultivated with activated macrophages. The relative survival, concentration of $\mathrm{NO}^{\circ}$ and mutation in the HPRT and TK1 genes of TK6 cells co-cultivated with macrophages for $24 \mathrm{~h}$ was determined (Fig. 3). Activated macrophages caused reduced $(38 \%)$ cell survival rates compared to controls $(100 \% ; \mathrm{P}<0.01)$, and 18.3-fold higher total $\mathrm{NO}^{\bullet}$ production compared with untreated controls $(\mathrm{P}<0.01$; Figs. $3 \mathrm{~A}$ and $\mathrm{B})$. The MFs induced in HPRT and TK1 genes $\left(8.8 \times 10^{-6}\right.$ and $13.9 \times 10^{-6}$, respectively) were 2.8 - and 1.9 -fold higher than the spontaneous MFs $\left(3.2 \times 10^{-6}\right.$ and $7.3 \times 10^{-6}$, respectively; $\mathrm{P}<0.05$; Fig. 3C). Co-treatment with both IFN- $\gamma /$ LPS and NMA restored cell survival to $95.5 \%$, completely blocked total $\mathrm{NO}^{\circ}$ and $\mathrm{NO}_{2}^{-}$production and strongly suppressed the increases in MF by 95 and $89 \%$, respectively, indicating that $\mathrm{NO}^{\circ}$ was largely responsible for the cytotoxicity and induced mutations in TK6 cells (Fig. 3; Table I). 


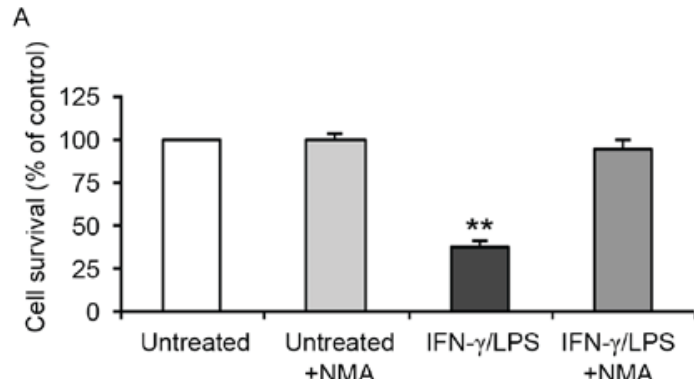

$\mathrm{B}$
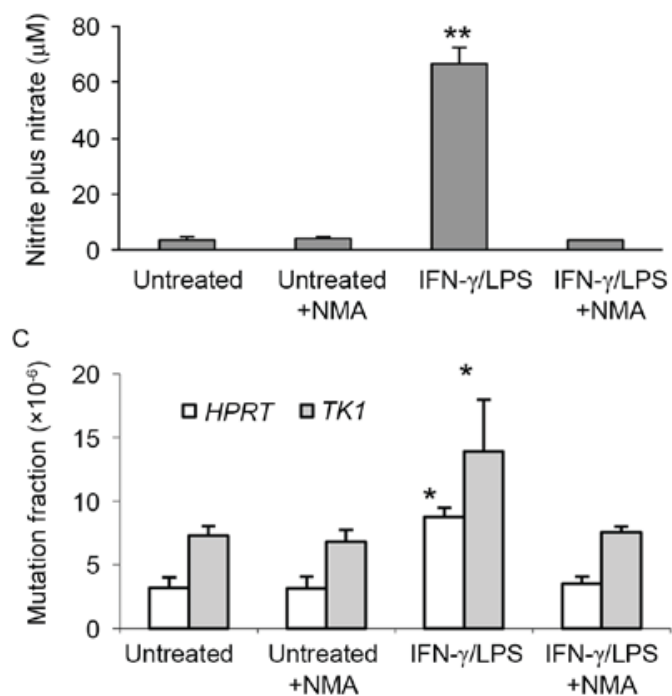

Figure 3. The effects nitric oxide $\left(\mathrm{NO}^{\circ}\right)$ on cell viability and mutation rates. Cell survival rates $(\mathrm{A})$, total $\mathrm{NO}^{-}$and nitrogen dioxide $\left(\mathrm{NO}_{2}^{-}\right)$ concentrations (B), and mutagenesis rates $(\mathrm{C})$ in the hypoxanthine-guanine phosphoribosyltransferase (HPRT) and thymidine kinase 1 (TK1) genes of TK6 cells co-cultivated with interferon- $\gamma /$ lipopolysaccharide-stimulated RAW264.7 cells in the absence or presence of methyl-L-arginine monoacetate (NMA). TK6 cells $\left(0.5 \times 10^{7}\right)$ were co-cultivated with macrophages $\left(1 \times 10^{7}\right)$ for $24 \mathrm{~h}$. Data represent mean \pm standard deviation for three measurements. ${ }^{*} \mathrm{P}<0.05$ and ${ }^{* *} \mathrm{P}<0.01$ vs. the untreated control.

Molecular analysis of HPRT mutants. For the molecular analysis of the HPRT mutations, RT-mediated production of HPRT cDNA, PCR amplification and cDNA sequencing were used to define small alterations sin the coding sequence. sRNA was extracted and analyzed from 22 and 48 mutants in argon and $540 \mu \mathrm{M}$ min of $\mathrm{NO}^{*}$ treatment groups in the reactor system, and 20 and 51 mutants in untreated and IFN- $\gamma /$ LPS-treatment groups in the co-culture system, respectively. Table II highlights the altered DNA sequences of 15 and $30 \mathrm{cDNA}$ products synthesized from 22 argon and $48 \mathrm{NO}^{\circ}$ treated HPRT mutants, respectively. Single base pair substitutions (60\%) were the major type of argon control mutations, with $\mathrm{G}: \mathrm{C}$ to $\mathrm{T}: \mathrm{A}$ transversions (13\%) and G:C to T:A $(13 \%)$ and $\mathrm{A}: \mathrm{T}$ to $\mathrm{G}: \mathrm{C}(13 \%)$ transitions. $20 \%(3 / 15)$ of mutants had base deletions and $13 \%$ $(2 / 15)$ had one complete exon exclusion. Similar mutation profiles were observed in $\mathrm{NO}^{\circ}$-induced mutants (Table II). Base substitutions were the predominant type of mutation (61\%), followed by single or two consecutive exon exclusions (23\%) and deletions (13\%). Of the 18 mutants carrying single base pair substitutions, an equal number occurred at $\mathrm{G}: \mathrm{C}(9 / 18)$ or A:T (9/18) base pairs with G:C to T:A (13\%) and A:T to T:A (13\%) transversions and G:C to A:T (13\%) and A:T to G:C $(13 \%)$ transitions. Among these, a clustering of base changes on exons 2 and 4 was observed in comparison to the spontaneous distribution. Four frame shift mutations, consisting of 1 or 2-bp deletions and 1-bp insertions occurred in exon 3.

In total, 30 of 51 HPRT mutants from TK6 cells co-cultivated with activated macrophages produced HPRT cDNA. These mutations included 54\% (16/30) base substitutions, $23 \%(7 / 30)$ single exon exclusions and 20\% (6/30) deletions (Table II). The proportion of point mutations at the $\mathrm{G}: \mathrm{C}$ and A:T base pairs was $56 \%(9 / 16)$ and $44 \%(7 / 16)$, respectively. The major base substitutions were G:C to T:A transversions (20\%) and A:T to $\mathrm{G}: \mathrm{C}$ transitions (17\%). $\mathrm{NO}^{\bullet}$ derived from co-culture system induced base substitutions that occurred most frequently in exons 2 and 3 of the HPRT gene (Table II). 8- to 16-bp deletions at positions between 387 and 402 occurred mostly frequently in exon 5 and were observed in the co-culture system. Analysis of spontaneous mutations that formed in the HPRT gene of TK6 cells co-cultivated with untreated macrophages revealed that $46 \%$ were base substitutions, $7 \%$ 1-bp deletions and $40 \%$ two exon exclusions (Table II).

\section{Discussion}

It has been previously demonstrated that the delivery method of $\mathrm{NO}^{\bullet}$ and ROS affects cellular responses, sometimes producing conflicting findings regarding cytotoxicity, apoptosis and mutation $(27,28)$. The present study has characterized the mutagenic effects in cells exposed to $\mathrm{NO}^{*}$ and $\mathrm{ROS}$ associated with inflammation through two delivery modes: A reactor system to deliver $\mathrm{NO}^{*}$ by diffusion into cell culture media at tightly controlled steady state concentrations $(16,24)$; and a co-culture system to expose target cells to $\mathrm{NO}^{*}$ and ROS generated by activated macrophages. In the first approach, cytotoxicity and mutagenesis were compared in TK6 cells exposed via a reactor system for delivering $\mathrm{NO}^{\bullet}$ at predictable, reproducible rates, and induced DNA damage in $\mathrm{CHO}$ cells comparable to those observed in the nuclear DNA of $\mathrm{NO}^{\circ}$-producing macrophages $(2,29)$. The results highlighted that $\mathrm{NO}^{\bullet}$ treatment reduced the percentage of viable cells dose-dependently (Fig. 1A), and mutagenic responses were characterized at total $\mathrm{NO}^{\circ}$ dose allowing $30 \%$ cell survival (540 $\mu \mathrm{M} / \mathrm{min} \mathrm{NO}^{*}$, closed square in Fig. 1A). Statistically significant mutagenic effects of $\mathrm{NO}^{\circ}$ have been observed previously, however the current study demonstrated that $\mathrm{NO}^{\circ}$ had a different mutagenic potency at the two endogenous HPRT and TK1 loci (Fig. 1B), consistent with earlier findings $(16,17,19,21)$. Continuous exposure of TK6 cells for $2 \mathrm{~h}$, at a rate of $533 \mathrm{nM} / \mathrm{s} \mathrm{NO}^{\circ}$, caused a 2-fold increase in HPRT and 4.2-fold in TK1 gene expression as compared with argon-treated controls $(17,21)$. These differences in susceptibility to mutations at the two loci may be explained by the fact that deletions $>1.3 \mathrm{Mbp}$ at the HPRT locus decreases cell viability (30-32), however, cells at the TK1 locus can tolerate much larger deletions (33). Furthermore, allelic recombination is possible at the autosomal TK1 locus but not at the X-linked hemizygous HPRT locus (34).

The present study also characterized the mutagenic potency of $\mathrm{NO}^{\bullet}$ and ROS produced by IFN- $\gamma /$ LPS activated macrophages using a modified Transwell ${ }^{\mathrm{TM}}$ co-culture system. Before examining mutagenic events in co-cultivated target cells, NO` and ROS production were assessed by macrophages activated with IFN- $\gamma /$ LPS using fluorescent probes specific 
Table I. Suppressive effects of NMA on total $\mathrm{NO}^{\bullet}$ and $\mathrm{NO}_{2}^{-}$production, mutagenesis, and cytotoxicity in TK6 cells co-cultured with IFN- $\gamma /$ LPS-stimulated RAW 264.7 cells.

\begin{tabular}{lcccc}
\hline & \multicolumn{3}{c}{ Inhibition (\%) } & Cytotoxicity, $\%$ \\
\cline { 2 - 4 } Treatment & Nitrite+Nitrate & Nitrite & Mutation & 62.0 \\
\hline IFN- $\gamma /$ LPS & - & & - & 4.5 \\
IFN- $\gamma /$ LPS+NMA & 100 & $99.7 \pm 1.44$ & $\frac{94.5 \pm 9.32(\text { HPRT) }}{89.2 \pm 5.69(\text { TKI) }}$ & \\
\hline
\end{tabular}

$\mathrm{NO}^{*}$, nitrogen oxide; $\mathrm{NO}_{2}{ }^{-}$, nitrogen dioxide radical; NMA, $N$-methyl-L-arginine monoacetate; IFN- $\gamma / \mathrm{LPS}$, interferon- $\gamma /$ lipopolysaccharide; $H P R T$, hypoxanthine-guanine phosphoribosyltransferase; $T K 1$, thymidine kinase.

Table II. A summary of results from the molecular analysis of human HPRT mutant TK6 cells treated with NO^ exposure by reactor or co-culture systems.

\begin{tabular}{|c|c|c|c|c|}
\hline & \multicolumn{4}{|c|}{ Proportion of mutants (\%) } \\
\hline & \multicolumn{2}{|c|}{ Reactor } & \multicolumn{2}{|c|}{ Co-culture } \\
\hline & Spontaneous ${ }^{\mathrm{a}}$ & $\mathrm{NO}^{\bullet}$-induced ${ }^{\mathrm{b}}$ & Spontaneous ${ }^{\mathrm{c}}$ & $\mathrm{NO}^{*}$-induced ${ }^{\complement}$ \\
\hline Transversion & $5(34)$ & $10(35)$ & $4(26)$ & $9(30)$ \\
\hline $\mathrm{G}: \mathrm{C}$ to $\mathrm{T}: \mathrm{A}$ & $2(13)$ & $4(13)$ & $1(7)$ & $6(20)$ \\
\hline $\mathrm{G}: \mathrm{C}$ to $\mathrm{C}: \mathrm{G}$ & $1(7)$ & $1(3)$ & $0(0)$ & $1(3)$ \\
\hline $\mathrm{A}: \mathrm{T}$ to $\mathrm{T}: \mathrm{A}$ & $1(7)$ & $4(13)$ & $2(13)$ & $1(3)$ \\
\hline$A: T$ to $C: G$ & $1(7)$ & $1(3)$ & $1(7)$ & $1(3)$ \\
\hline Transition & $4(26)$ & $8(26)$ & $3(20)$ & $7(24)$ \\
\hline $\mathrm{G}: \mathrm{C}$ to $\mathrm{A}: \mathrm{T}$ & $2(13)$ & $4(13)$ & $2(13)$ & $2(7)$ \\
\hline A:T to $\mathrm{G}: \mathrm{C}$ & $2(13)$ & $4(13)$ & $1(7)$ & $5(17)$ \\
\hline Insertions & $1(7)$ & $1(3)$ & $0(0)$ & $0(0)$ \\
\hline Deletions & $3(20)$ & $4(13)$ & $1(7)$ & $6(20)$ \\
\hline Multiple & $0(0)$ & $0(0)$ & $1(6)$ & $1(3)$ \\
\hline Exon exclusions & $2(13)$ & $7(23)$ & $6(40)$ & $7(23)$ \\
\hline One exon & $2(13)$ & $1(3)$ & $0(0)$ & $7(23)$ \\
\hline Two exon & $0(0)$ & $6(20)$ & $6(40)$ & $0(0)$ \\
\hline Total & $15(100)$ & $30(100)$ & $15(100)$ & $30(100)$ \\
\hline
\end{tabular}

${ }^{\mathrm{a} C e l l s ~ e x p o s e d ~ t o ~ a r g o n ~ g a s ~ u n d e r ~ t h e ~ s a m e ~ c o n d i t i o n s ~ s e r v e d ~ a s ~ n e g a t i v e ~ c o n t r o l s ; ~}{ }^{\mathrm{b}} \mathrm{Cells}$ exposed to $540 \mu \mathrm{M}$ min of NO; ${ }^{\mathrm{c}} \mathrm{Untreated}$ cells served as a negative control; and ${ }^{\mathrm{d} C e l l s ~ c o-c u l t i v a t e d ~ w i t h ~ I F N-~} \gamma /$ LPS-stimulated RAW264.7 cells for 24 h. NO', Nitric oxide; HPRT, hypoxanthine-guanine phosphoribosyltransferase; IFN- $\gamma /$ LPS, interferon- $\gamma /$ lipopolysaccharide.

for these factors (Fig. 2). Upon activation, macrophages produced $\mathrm{NO}^{\circ}$ and $\mathrm{ROS}$, detected at the intracellular level by specific probes and at the extracellular level through the formation of $\mathrm{NO}_{3}^{-}$and $\mathrm{NO}_{2}^{-}$, the metabolites of $\mathrm{NO}^{-}$in cell supernatants (Fig. 3B; Table I). These data expand on previous results $(35,36)$, demonstrating that $\mathrm{NO}^{\bullet}$ concentration after $8 \mathrm{~h}$ activation approached a plateau of $0.6 \mu \mathrm{M}$ at $\sim 34 \mathrm{~min}$ as well as a substantial increase in $\mathrm{O}_{2}^{--}$production by activated macrophages. These findings are further substantiated by decreases in fluorescence intensity of probes specific for $\mathrm{NO}^{\circ}$ and $\mathrm{ROS}$ caused by NMA, an $\mathrm{NO}^{-}$synthase inhibitor, and $\mathrm{O}_{2}{ }^{-}$and/or $\mathrm{ONOO}^{-}$scavengers (Fig. 2).
Previous co-culture studies indicated that NO ${ }^{\bullet}$ and ROS produced by macrophages were lethal and strongly mutagenic in both target cells and generator cells $(17,18,20)$. Others have demonstrated that products of IFN- $\gamma / \mathrm{LPS}-$ stimulated RAW264.7 or TPA-stimulated HL-60 cells induced mutagenesis in AS52 cells exposed in mixed co-culture systems (37). As well as increased MF, high levels of 8-hydroxy-2'-deoxyguanosine, reflecting oxidative DNA damage have been detected in AS52 co-cultivated with both types of generator cells $(37,38)$. Suppressors of $\mathrm{NO}^{*}$ and ROS strongly inhibited MF (38-41), supporting the conclusion that $\mathrm{NO}^{\circ}$ and ROS are major causes of induced mutations. 
In the present study, a Transwell ${ }^{\mathrm{TM}}$ system was used that permits cell-cell communication through diffusible soluble factors independent of cell-cell contact, in contrast to the co-culture systems used in previous studies. These allow direct generator-target cell contact, potentially maximizing the transfer of reactive species from generator to target cells, which could amplify estimates of target cell exposure in inflamed tissues. Additionally, macrophage and target cells share the same medium without cell-cell interactions, owing to the physical separation of cells by a polycarbonate membrane. Using the Transwell ${ }^{\mathrm{TM}}$ co-culture system, activation of macrophages increased production of $\mathrm{NO}^{\bullet}$ and the MF of TK6 cells as compared to unstimulated controls (Fig. 3; Table I). By employing an $\mathrm{NO}^{\bullet}$ synthase inhibitor, the relative contribution of $\mathrm{NO}^{*}$ to mutagenesis in this system was assessed. Inhibition of $\mathrm{NO}^{\bullet}$ production through addition of NMA to the culture medium abrogated much of the cytotoxicity and genotoxicity in TK6 cells, confirming the role of $\mathrm{NO}^{\circ}$ in inducing these effects (Fig. 3; Table I). A contributing factor may have been distances between $\mathrm{NO}^{\circ}$ generator and target cells, due to TK6 cells settling out of suspension were less uniformly distributed than adherent cells growing in close proximity relative to the monolayer of macrophages. $\mathrm{O}_{2}{ }^{--}$and $\mathrm{ONOO}^{-}$-derived $\mathrm{ROS}$ have much shorter half-lives $(<50 \mathrm{~ms})$ than $\mathrm{NO}^{\circ}$ and shorter diffusion radii, thus they may not have reached effective concentrations in proximity to TK6 cells above the monolayer of adherent macrophages $(17,18)$.

Mutagenesis induced by $\mathrm{NO}^{\bullet}$ has previously been examined in a number of experimental systems. Exposure of S.typhimurium to $\mathrm{NO}^{\circ}$ gas induced G:C to T:A, T:A to A:T, and $\mathrm{C}: \mathrm{G}$ to A:T mutations (19), and also mutagenized TK6 cells, causing A:T to T:A and A:T to G:C mutations in the HPRT gene (19). Peroxynitrite, the reaction product of $\mathrm{NO}^{\circ}$ and superoxide, also induced pSP189 supF mutations, predominantly G:C to T:A $(10,15)$. G:C to T:A mutations occurred in the supF gene of pSP189 replicating in AD293 cells co-cultivated with activated macrophages (18). Treatment of the same plasmid with $\mathrm{NO}^{*}$ donor drugs (diethylamine/NO${ }^{*}$ or spermine/NO ${ }^{*}$ complexes) induced predominantly $\mathrm{G}: \mathrm{C}$ to $\mathrm{A}: \mathrm{T}$ and $\mathrm{A}: \mathrm{T}$ to $\mathrm{G}: \mathrm{C}$ mutations (42). In each of these experimental systems, base substitutions were the main type of mutations induced, the specific type depended on the form of $\mathrm{NO}^{\bullet}$ used.

In the present study, the majority of spontaneous and $\mathrm{NO}^{\circ}$ induced mutations were single base pair substitutions, with transversions (30-35\%) outnumbering transitions (24-26\%). Other mutations were deletions and an insertion in both reactor and co-culture systems (Table II). 29-30 and 23-29\% of mutations occurred at G:C and A:T base pairs, respectively, and G:C to T:A transversions (13-20\%) and A:T to G:C transitions (13-17\%) were the single base pair substitutions most often induced by $\mathrm{NO}^{*}$ treatment in both delivery systems (Table II). In human cancer, a significant proportion of mutations in oncogenes and tumor suppressor genes are G:C to T:A transversions, particularly in lung cancer $(43,44)$. Previous studies have demonstrated that these mutations may be caused by a variety of DNA lesions, such as apurinic sites, 8-oxodeoxyguanosine (8-oxo-dG), or 8-nitroguanine (8-nitro-G; (45-47). ROS-associated G:C to T:A transversions may arise from oxidative damage, leading to $\mathrm{dA}$ rather than $\mathrm{dC}$ being incorporated opposite $\mathrm{dG}$. A:T to G:C transitions, generally induced by oxidative damage (19), were also frequently observed (Table II). Deamination of adenine to hypoxanthine, which pairs with cytosine rather than thymine in DNA, could account for the high proportion of A:T to G:C transitions observed (19). The predominance of $\mathrm{G}: \mathrm{C}$ to $\mathrm{T}: \mathrm{A}$ transversions is consistent with previously reported mutation types induced by peroxynitrite $\left(\mathrm{ONOO}^{-}\right)$and its derivatives generated by reaction of $\mathrm{NO}^{\circ}$ with $\mathrm{O}_{2}{ }^{-}(10,15,18)$ and $\mathrm{NO}^{\bullet}$ gas $(42)$, suggesting that $\mathrm{NO}^{\bullet}$ may be a major contributor to the observed mutagenesis.

To conclude, the present study provides evidence that exposure to $\mathrm{NO}^{\circ}$ induces cytotoxicity and mutagenicity in target cells and that inhibition of $\mathrm{NO}^{\bullet}$ production by activated macrophages is effective at abrogating these properties. Moreover, both the delivery method of $\mathrm{NO}^{*}$ and target genes at which the TK6 cells are exposed was revealed to strongly influence the cytotoxicity, the mutagenic potency, types and distribution of mutations. The systems used to introduce NO in these experiments were designed to approximate conditions of exposure physiologically relevant to chronic inflammation states. Further studies will be required to elucidate precise mechanisms underlying these effects and their potential relevance to $\mathrm{NO}^{\bullet}$ induced genotoxicity in vivo.

\section{Acknowledgements}

This work was supported by Basic Science Research Program (no. 2016R1A6A1A03012862 and no. 2014R1A1A2056292) through the National Research Foundation of Korea (NRF) funded by the Ministry of Education, Science and Technology, Republic of Korea.

\section{References}

1. Dedon PC and Tannenbaum SR: Reactive nitrogen species in the chemical biology of inflammation. Arch Biochem Biophys 423: 12-22, 2004.

2. Li CQ and Wogan GN: Nitric oxide as a modulator of apoptosis. Cancer Lett 226: 1-15, 2005.

3. Ohshima H, Tatemichi M and Sawa T: Chemical basis of inflammation-induced carcinogenesis. Arch Biochem Biophys 417: 3-11, 2003.

4. Czapski G and Goldstein S: The role of the reactions of .NO with superoxide and oxygen in biological systems: A kinetic approach. Free Radic Biol Med 19: 785-794, 1995.

5. Chanock SJ, el Benna J, Smith RM and Babior BM: The respiratory burst oxidase. J Biol Chem 269: 24519-24522, 1994.

6. Ohshima $\mathrm{H}$ and Bartsch $\mathrm{H}$ : Chronic infections and inflammatory processes as cancer risk factors: Possible role of nitric oxide in carcinogenesis. Mutat Res 305: 253-264, 1994.

7. Vamvakas S and Schmidt HH: Just say NO to cancer? J Natl Cancer Inst 89: 406-407, 1997.

8. Wiseman $\mathrm{H}$ and Halliwell B: Damage to DNA by reactive oxygen and nitrogen species: Role in inflammatory disease and progression to cancer. Biochem J 313: 17-29, 1996.

9. MacMicking J, Xie QW and Nathan C: Nitric oxide and macrophage function. Annu Rev Immunol 15: 323-350, 1997.

10. Juedes MJ and Wogan GN: Peroxynitrite-induced mutation spectra of pSP189 following replication in bacteria and in human cells. Mutat Res 349: 51-61, 1996.

11. Jeong JK, Juedes MJ and Wogan GN: Mutations induced in the supF gene of pSP189 by hydroxyl radical and singlet oxygen: Relevance to peroxynitrite mutagenesis. Chem Res Toxicol 11: 550-556, 1998.

12. Tretyakova NY, Burney S, Pamir B, Wishnok JS, Dedon PC, Wogan GN and Tannenbaum SR: Peroxynitrite-induced DNA damage in the supF gene: Correlation with the mutational spectrum. Mutat Res 447: 287-303, 2000

13. Pamir B and Wogan GN: Carbon dioxide modulation of peroxynitrite-induced mutagenesis of the supF gene in pSP189. Chem Res Toxicol 16: 487-492, 2003. 
14. Li CQ, Trudel LJ and Wogan GN: Genotoxicity, mitochondria damage and apoptosis in human lymphoblastoid cells exposed to peroxynitrite generated from SIN-1. Chem Res Toxicol 15: 527-535, 2002.

15. Kim MY, Dong M, Dedon PC and Wogan GN: Effects of peroxynitrite dose and dose rate on DNA damage and mutation in the supF shuttle vector. Chem Res Toxicol 18: 76-86, 2005.

16. Li CQ, Pang B, Kiziltepe T, Trudel LJ, Engelward BP, Dedon PC and Wogan GN: Threshold effects of nitric oxide-induced toxicity and cellular responses in wild-type and p53-null human lymphoblastoid cells. Chem Res Toxicol 19: 399-406, 2006.

17. Zhuang JC, Lin D, Lin C, Jethwaney D and Wogan GN: Genotoxicity associated with NO production in macrophages and co-cultured target cells. Free Radic Biol Med 33: 94-102, 2002.

18. Kim MY and Wogan GN: Mutagenesis of the supF gene of pSP189 replicating in AD293 cells cocultivated with activated macrophages: Roles of nitric oxide and reactive oxygen species. Chem Res Toxicol 19: 1483-1491, 2006.

19. Zhuang JC, Wright TL, deRojas-Walker T, Tannenbaum SR and Wogan GN: Nitric oxide-induced mutations in the HPRT gene of human lymphoblastoid TK6 cells and in Salmonella typhimurium. Environ Mol Mutagen 35: 39-47, 2000.

20. Zhuang JC, Lin C, Lin D and Wogan GN: Mutagenesis associated with nitric oxide production in macrophages. Proc Natl Acad Sci USA 95: 8286-8291, 1998.

21. Li CQ, Trudel LJ and Wogan GN: Nitric oxide-induced genotoxicity, mitochondrial damage and apoptosis in human lymphoblastoid cells expressing wild-type and mutant p53. Proc Natl Acad Sci USA 99: 10364-10369, 2002

22. Li CQ, Robles AI, Hanigan CL, Hofseth LJ, Trudel LJ, Harris CC and Wogan GN: Apoptotic signaling pathways induced by nitric oxide in human lymphoblastoid cells expressing wild-type or mutant p53. Cancer Res 64: 3022-3029, 2004.

23. Li CQ, Wright TL, Dong M, Dommels YE, Trudel LJ, Dedon PC, Tannenbaum SR and Wogan GN: Biological role of glutathione in nitric oxide-induced toxicity in cell culture and animal models. Free Radic Biol Med 39: 1489-1498, 2005.

24. Wang $C$ and Deen WM: Nitric oxide delivery system for cell culture studies. Ann Biomed Eng 31: 65-79, 2003.

25. Yang JL, Maher VM and McCormick JJ: Amplification and direct nucleotide sequencing of cDNA from the lysate of low numbers of diploid human cells. Gene 83: 347-354, 1989.

26. Hsie AW, Recio L, Katz DS, Lee CQ, Wagner $M$ and Schenley RL: Evidence for reactive oxygen species inducing mutations in mammalian cells. Proc Natl Acad Sci USA 83: 9616-9620, 1986.

27. Patel RP, McAndrew J, Sellak H, White CR, Jo H, Freeman BA and Darley-Usmar VM: Biological aspects of reactive nitrogen species. Biochim Biophys Acta 1411: 385-400, 1999.

28. Miller MR and Megson IL: Recent developments in nitric oxide donor drugs. Br J Pharmacol 151: 305-321, 2007.

29. Tamir S, Lewis RS, de Rojas Walker T, Deen WM, Wishnok JS and Tannenbaum SR: The influence of delivery rate on the chemistry and biological effects of nitric oxide. Chem Res Toxicol 6: 895-899, 1993.

30. Nelson SL, Jones IM, Fuscoe JC, Burkhart-Schultz K and Grosovsky AJ: Mapping the end points of large deletions affecting the hprt locus in human peripheral blood cells and cell lines. Radiat Res 141: 2-10, 1995.

31. Phillips EN, Xia F, Kelsey KT and Liber HL: Spectra of spontaneous and X-ray-induced mutations at the hprt locus in related human lymphoblast cell lines that express wild-type or mutant p53. Radiat Res 143: 255-262, 1995.
32. Yamada Y, Park MS, Okinaka RT and Chen DJ: Molecular analysis and comparison of radiation-induced large deletions of the HPRT locus in primary human skin fibroblasts. Radiat Res 145: 481-490, 1996.

33. Giver CR and Grosovsky AJ: Radiation specific patterns of loss of heterozygosity on chromosome 17q. Mutat Res 450: 201-209, 2000.

34. Wiese C, Gauny SS, Liu WC, Cherbonnel-Lasserre CL and Kronenberg A: Different mechanisms of radiation-induced loss of heterozygosity in two human lymphoid cell lines from a single donor. Cancer Res 61: 1129-1137, 2001.

35. Lewis RS, Tamir S, Tannenbaum SR and Deen WM: Kinetic analysis of the fate of nitric oxide synthesized by macrophages in vitro. J Biol Chem 270: 29350-29355, 1995.

36. Nalwaya $\mathrm{N}$ and Deen WM: Nitric oxide, oxygen, and superoxide formation and consumption in macrophage cultures. Chem Res Toxicol 18: 486-493, 2005.

37. Kim HW, Murakami A, Williams MV and Ohigashi H: Mutagenicity of reactive oxygen and nitrogen species as detected by co-culture of activated inflammatory leukocytes and AS52 cells. Carcinogenesis 24: 235-241, 2003

38. Murakami A, Takahashi D, Kinoshita T, Koshimizu K, Kim HW, Yoshihiro A, Nakamura Y, Jiwajinda S, Terao J and Ohigashi H: Zerumbone, a Southeast Asian ginger sesquiterpene, markedly suppresses free radical generation, proinflammatory protein production and cancer cell proliferation accompanied by apoptosis: The alpha,beta-unsaturated carbonyl group is a prerequisite. Carcinogenesis 23: 795-802, 2002.

39. Kim HW, Murakami A, Abe M, Ozawa Y, Morimitsu Y, Williams MV and Ohigashi H: Suppressive effects of mioga ginger and ginger constituents on reactive oxygen and nitrogen species generation and the expression of inducible pro-inflammatory genes in macrophages. Antioxid Redox Signal 7: 1621-1629, 2005.

40. Kim HW, Murakami A, Williams MV and Ohigashi $\mathrm{H}$ : Suppressive effects of selected antioxidants on the activated leukocytes-induced mutagenesis in the co-culture assay systems. Biosci Biotechnol Biochem 68: 238-242, 2004.

41. Kim HW, Murakami A, Nakamura Y and Ohigashi H: Screening of edible Japanese plants for suppressive effects on phorbol ester-induced superoxide generation in differentiated HL-60 cells and AS52 cells. Cancer Lett 176: 7-16, 2002.

42. Routledge MN, Wink DA, Keefer LK and Dipple A: DNA sequence changes induced by two nitric oxide donor drugs in the supF assay. Chem Res Toxicol 7: 628-632, 1994.

43. Bennett WP, Hussain SP, Vahakangas KH, Khan MA, Shields PG and Harris CC: Molecular epidemiology of human cancer risk: Gene-environment interactions and p53 mutation spectrum in human lung cancer. J Pathol 187: 8-18, 1999.

44. Hainaut P and Pfeifer GP: Patterns of $\mathrm{p} 53 \mathrm{G} \rightarrow \mathrm{T}$ transversions in lung cancers reflect the primary mutagenic signature of DNA-damage by tobacco smoke. Carcinogenesis 22: 367-374, 2001.

45. Wang D, Kreutzer DA and Essigmann JM: Mutagenicity and repair of oxidative DNA damage: Insights from studies using defined lesions. Mutat Res 400: 99-115, 1998.

46. Shibutani S, Takeshita M and Grollman AP: Insertion of specific bases during DNA synthesis past the oxidation-damaged base 8-oxodG. Nature 349: 431-434, 1991.

47. Moriya M: Single-stranded shuttle phagemid for mutagenesis studies in mammalian cells: 8-oxoguanine in DNA induces targeted G.C- $>$ T.A transversions in simian kidney cells. Proc Natl Acad Sci USA 90: 1122-1126, 1993. 